\title{
Women's Role in the Development of Alternative Tourism Projects in Indigenous Areas in the State of Morelos, Mexico
}

\author{
Norma Angélica Juárez Salomo \\ Autonomous University of the State of Morelos
}

\begin{abstract}
The rural lands of Morelos have a wide variety of natural resources and it's rich in cultural heritage. Here you can find indigenous groups, mostly Nahuatl, distinguished by their hospitality. They offer multiple recreational activities to the tourists such as hiking, aerial games on trees, water tours, rock art, coexistence with indigenous communities, guided visits to "magical towns", conventual or historical routes, among other attractions.
\end{abstract}

For the Nahua people, tlazohtla love and talcaiita respect are linked to tequio reciprocity, strengthening collective work. Some initiatives have emerged thanks to the efforts of the community, and in a very special way to the women, preserving and sharing their ancestral knowledge and culture day after day, reinforcing values, solidarity, and commitment to the place of belonging.

This paper shares some collaborative initiatives between rural indigenous collectives and researchers from the Autonomous University of the State of Morelos that promote the value of the impact of indigenous women's proposals for the development of ecotourism.

Keywords: rural development, ecotourism, community, women

\section{INTRODUCTION}

With a strong commitment to environmental protection and deep respect for ancestral cultures, university and community groups from Morelos direct their efforts and resources towards alternative tourism projects that, in addition to proposing business options for local inhabitants, respect the material and immaterial heritage of the region.

Using a mixed methodology that involves specialists from various areas of knowledge among which are experts in tourism, architects, biologists, it has been possible to achieve a more comprehensive understanding. For example, they perform works in various communities, carrying out the historical review and preservation of resource management, gastronomy, biodiversity, and identification of potential tourism. Among other aspects, there is the general strategies through which initiatives have been implemented for the development of educational tourism and ecotourism to contribute with the recognition and value of the natural and cultural heritage of the indigenous rural communities, illustrating the cases of three existing projects carried out by entrepreneurs women in the towns of Santa María Ahuacatitlán, Puente de Ixtla (El Zapote community) and the town of Tlayacapan (Mexico). 


\section{WHY ALTERNATIVE/RURAL TOURISM PROJECTS?}

The alternative/rural tourism project starts from the idea of achieving a better quality of life in society (Royal Spanish Academy, 2017) an idea that from the beginning offers a challenge by having to translate the idea of "better quality of life" in the face of diversity.

The concept of "rural", is about working in areas of low-density population, whose economies are based on the elaboration of a few products from natural resources, located in remote places. But more than geographical location, as Graciet refers to it, rural spaces are usually traditional, vital, and cultural spaces that contribute to forging cultural diversity and national identity (Graciet, 1994).

The definition of rural areas does not always have clear boundaries. Sometimes it refers to spaces where agricultural activities are carried out or the areas of nature where the towns and villages are located, it's also linked to the concept of the countryside or everything that is not an urban agglomeration and, in some cases, it's even linked to the spaces of residual territories. The rural on the other hand, when used as an adjective, is related to land in the countryside, considering also the working lands, the crops, and the sowing land (Graciet, 1994).

Connecting the concepts of development + rural, then "better quality of life" will be linked to traditional living spaces and with an identity linked to the countryside and everything that develops in it, and that also impacts on well-being, health, and the possibility of having support; also it will be the main target for the development of projects. To complete the triad, the community adds a larger identity component.

Other related concepts are ecotourism, which refers to the pursuit of knowledge of flora and fauna, the environmental protection and sustainability; agrotourism, whose basis is the realization of activities related to the land such as learning to cultivate, to take care of animals, to elaborate artisanal products and to cook traditional recipes; or ethno-tourism, focused on knowledge and coexistence with the inhabitants of the region, their customs, gastronomy or similar aspects. It's possible to say that, for rural tourism, each approach is inclusive, rather than exclusive.

\section{COMMUNITY AND TOURISM IN INDIGENOUS RURAL AREAS}

The foundation of rural indigenous communities is based on the sense of belonging to a group that defines and identifies its members by their forms of organization and their social, cultural, and historical characteristics, making a difference between "self-identity" and "what is foreign". Ancestral knowledge, traditional and popular festivals, traditional food, and even the relationship with nature are invaluable resources to share and, of course, they are subsistence sources with identity and a sense of belonging.

The Intangible Heritage of the communities lies in spoken traditions, including Nahuatl, a language that serves as a vehicle for intangible cultural heritage; performing arts such as traditional music, dance, and theatre, including social practices, rituals, and festive events, also the knowledge related to nature and the universe and even in traditional craft techniques.

The 2003 Convention for the Safeguarding of the Intangible Cultural Heritage has defined intangible cultural heritage more specifically as the practices, representations, expressions, knowledge, and skills that communities, groups, and individuals recognize as an integral part of their cultural heritage (UNESCO, 2006). The Convention includes objects, artifacts, and cultural places related to the manifestations of the heritage and includes the possibility of effective cooperation with other international normative instruments.

The definition of the Convention also includes that knowledge, considered as an intangible cultural heritage that, in the case of indigenous communities, meets the following criteria directly:

- They are transmitted from generation to generation;

- They are constantly recreated by communities and groups depending on their environment, their interaction with nature, and their history;

- They share their sense of identity and continuity to communities and groups;

- They promote respect for cultural diversity and human creativity;

- They are compatible with existing international human rights instruments; 
- They meet the imperatives of mutual respect among communities, groups, and individuals while supporting sustainable development.

- They respect the relationship and differences between tangible and intangible heritage and the protection and safeguarding of both.

Understanding the value of biodiversity, heritage, and planetary cultural richness contributes, clearly and importantly, to the comprehension of the world, its complexity, its richness, and the imperative need to promote its conservation in a sense of peace in the best possible conditions.

\section{CREATIVE DEVELOPMENT OF COMMUNITY TOURISM PROPOSALS}

Offering innovative proposals sets a challenge for the tourism sector that requires entrepreneurial approaches for the diversification and creative development of products, as well as the consolidation of integral development of tourist destinations, taking advantage of the competitive benefits within each region. Competitiveness in the tourism sector and its productive performance depend on the use of resources in an orderly and efficient manner, to generate greater added value, wealth, and well-being, elements for regional and social development (UNWTO, 2016).

According to the World Tourism Organization (2016), competitiveness is defined as the effectiveness of destinations to attract and satisfy visitors, the policies adopted by countries to make their tourism economies more competitive are becoming more relevant. The Organization for Economic Co-operation and Development (Gurría, 2012) defines the competitiveness of a tourist destination as its ability to optimize its interest in residents and non-residents; and provide quality, innovative and creative services to consumers, while ensuring that the resources that support tourism are used efficiently and sustainably.

Based on both definitions, the aspects to be considered for the competitiveness of rural tourist destinations require the harmonious development of the elements that allow them to position themselves as reliable, attractive, and sustainable destinations. Among the primary factors are considered the following (UNWTO, 2016):

- Productivity: Use of tourism resources in an orderly and efficient way that generates greater added value, wealth, and well-being.

- Innovation: Possibility to perform activities and functions creatively and that allows a destination to be more efficient and profitable while ensuring the continuous improvement of the visitor experience.

- Diversification: Ability to deliver new products to both current and potential consumers.

- Specialization: Ability to deliver unique experiences to specific market segments and independent travelers.

- Professionalization: Planning, management, monitoring, and control of human resources aligned with the strategic objectives of the sector.

- Sustainability: Fully consider current and future economic, social and environmental impacts to meet the needs of visitors, industry, environment, and host communities.

A growing trend in the world is the development of sustainable tourism projects that allow us to rethink not only the development patterns of destinations but also the consumption patterns that demand cleaner, safer, and more environmentally responsible destinations. Sustainability as a true balance between the resources of the environment is configured through three dimensions: economic, social, and environmental (Tarlombani, 2005).

\section{ENTREPRENEURIAL WOMEN AND INDIGENOUS TOURISM}

The tourist activity, depending on its forms of realization, theoretical frameworks, and/or concepts, has been accompanied for its explanation by nouns or adjectives that help to define it and emphasize its approaches. Urban Tourism, Adventure Tourism, Extreme Tourism, Ecotourism, among many other denominations, refer to an emphasis on action. Within these duos, and for the topic addressed here, it's 
important to add the term Indigenous Tourism, which emphasizes the link of tourism activity with the respect and express knowledge of the peoples including their daily manifestations, their festivities, their material, and spiritual productions, their regional roots, and location, as well as their historical roots.

Indigenous Tourism raises the harmonious relationship with nature, considering the natural environment as an attraction and tourist scenario, where the main motivation of tourists is the observation and appreciation of nature or the dominant traditional cultures found there (Fullana, 2002). In a country like Mexico, where there are diverse cultural expressions and more than 65 indigenous peoples, indigenous tourism allows the intercultural understanding of society by promoting respect for the peoples and cultures.

The growing need to seek and achieve the sustainability of cultural and environmental heritage is a task that requires knowledge and organization. Therefore, the participation of multiple actors, in addition to the inhabitants themselves, is essential to achieve actual initiatives. In addition to the permanent collaboration of academics and government agencies, various organizations have been integrated to recover experiences and deepen emerging tourism initiatives. The RITA (the Indigenous Tourism Network of Mexico, Spanish Acronym) for example, is a civil association of diverse companies, whose purpose is to make its associates advance and progress through the "... full exercise of the fundamental and specific rights of indigenous peoples, recognized by the Mexican State and at international level in the economic, social, cultural, environmental and political configuration. Participatively integrating strategies for human, social, economic and productive strengthening" (RITA, 2017).

A growing number of communities in Mexico have envisioned in Indigenous Tourism an alternative to reduce the economic backwardness. Therefore its ecotourism pillar is seen as an option for the generation of resources for a dignified life, the conservation of their natural and/or cultural resources, and a way to reaffirm their identity achieving recognition and respect for their community, and in a very special way have emerged projects proposed by women who, in the absence of a partner or because of the growing needs of the family, have gone to various instances to have the guidance and/or financial support to be able to undertake projects and give work to their communities and survive. Through the work carried out, it has been possible to verify that the conception of the works, considering the role of mothers, heads of families, and community leaders, give the projects a very special charisma, making "the female presence" present in all activities. In a very simple way, the women of the communities express their main concern like this "if it's cold, how would I cover my son?".

Giving tiny but consistent steps, the communities, and in a very special way the women, understand that to be able to recover and project "their people", it's necessary to have organizational, theoretical, and management bases that allow to shorten times and obtain better results and in this topic is where strategic allies such as students and university researchers, can intervene to accompany, guide and monitor the development and progress of the work, as has happened in the case of the projects subject to this study.

\section{COMMUNITIES WITH VALUE}

The towns in which this work was done, as mentioned, are Santa María Ahuacatitlán, Puente de Ixtla and Tlayacapan. The three towns are located in different areas of the State of Morelos and offer similar characteristics in terms of ethnicity and language, but the characteristics of the projects and tourist offer vary.

\section{Ecotourism Project in El Zapote Community (Ixtla Bridge, Morelos)}

El Zapote is located in the municipality of Puente de Ixtla, which has only 97 inhabitants and is located 1789 meters high. The town is inhabited by 54 men and 43 women with education of no more than 6 years.

It is a forested community that has a huge variety of plants and fungi, as well as a very varied fauna. Between the hills of Morelos is the so-called "El Cerro Frío" and in the upper part is found the small rural community "El Zapote", belonging to Puente de Ixtla.

In addition to the family gardens and the care of some animals, the community has seen in ecotourism a way not only to generate income but to seek the existence of the community, in which identification and recovery work has begun some months ago, as well as the search for alternative trails, gastronomy, and 
traditional medicine. The work has been developed mainly with a group of women from the community organized by Doña Rosenda.

\section{Women Potters Project (Tlayacapan, Morelos)}

Ancestrally, the pottery trade in Tlayacapan was distinguished by being an activity eminently carried out mainly by men who carried out the modeling and baking of large pieces and the work of women is barely mentioned. However, in 2000 and as a result of the valuations to obtain the denomination of "Magic Town" in Tlayacapan, the importance of female participation in this trade, in the marketing processes, if they were collaborators or owners of craft workshops was documented.

Thanks to the emergence of roads and the work of intermediaries and producers of ornate figures, the new generations and especially women have stood out projecting the community with a touch of equity.

In the present, in the village, a huge and varied number of ceramic objects are worked, ranging from traditional kitchen appliances, ritual pottery, and the figures of clay ornament and, to a lesser extent, ceramics. They are sold wholesale through various intermediaries, who in turn supply the owners of stores that sell Mexican goods for tourism, either at airports or in shopping centers of tourist cities of the country such as Guerrero, Oaxaca, Puebla, State of Mexico, Yucatan.

\section{Ecotourism Project the Blue Mushroom Forest (Santa María Ahuacatitlán, Morelos)}

The Project whose initial name was "El Cajetito" (-Little Bowl- name of the area where the project is located) is immersed in the Mexican Flora and Fauna Protection Areas "Chichinautzin Biological Corridor" (DOF, 1988) site, considered ideal for its proximity to the cities of Mexico and Cuernavaca, the exuberance of its vegetation, the diversity of species and the little thermal variation. The area in question allows the permanent enjoyment of a temperate climate, which without being extreme is cool at nights and when it's very hot during daytime it offers wind that provides pleasant conditions for the development of activities such as outdoor camping and walks through the forest and is one of the projects with the highest level of progress.

In addition to the numerous natural attractions of the area, Santa María Ahuacatitlán, among the most important things, are its ancestral knowledge, its archaeological vestiges, its festivities, and its monumental heritage buildings suited for the development of tourist activities that if they are properly managed, they can benefit the community, preserving its traditional values, respect for its culture and the right to decide based on its development priorities (SEMARNAT, 2012).

In the three project towns, progress in the recovery of knowledge and culture of the population is shared, by involving academics and students from the Autonomous University of the State of Morelos, who have participated in the project highlighting the need to make rational use of natural resources, from their areas of specialty, and the conservation of the environment. Finally, among the initiatives carried out, the level of progress is as follows:

As can be seen in Table 1, the level of progress of each project varies, with "The Blue Mushroom Forest" being one of the most advanced. Academics, undergraduate and graduate students of Tourism, Architecture, Education, Humanities, Biology, and Law have participated here, giving rise to various research projects. The project has been presented in national and international scenarios after almost three years of permanent work, and the coordination team with community members and university representatives has been established. One of the main features and hallmarks of the project is the Lactarius Indigo which is a species of fungus that grows in this region, but also the success in obtaining funding from the National Commission for the Development of the Indigenous Peoples (CDI, Spanish Acronym).

\section{CONCLUSIONS}

Reflecting on the concepts that define community rural development and underlining the importance of knowledge, it's important to analyze the environment in which the projects take place in a specific way, to assess their alternatives and priorities. In a country like Mexico, there are not only consolidated proposals but also areas of opportunity to develop attractive and sustainable tourism products in the field of rural 
tourism. However, there is lacking obviously, in terms of infrastructure and human resources sufficiently trained to provide quality care and service, which limits the flow of tourists (Datatur, 2012).

For Indigenous Tourism, the environment does not represent an obstacle but a resource, an opportunity of great wealth for communities. Sustainable tourism allows a change of perspective: it ceases to be a predatory activity of our century and rises as an invaluable resource to prevent environmental degradation.

The field of Indigenous Tourism, like much of the human activities in the world, is a reflection and a product of social transformations. The dynamics of communication, technologies, the emerging phenomena of the globalization process set the trend, causing products and services in various sectors, to be increasingly specialized, focused on quality, and related to the needs of individuals who, after trying multiple options realize the paradox: nature, so influenced by the environmental movement that, more than a fashion, it extends to society in general, marking a lifestyle and an alternative to encounter with the being.

\section{ACKNOWLEDGEMENT}

Translated \& edited by American Publishing Services (https://americanpublishingservices.com/).

\section{REFERENCES}

Alternative Tourism Development Directorate. (2006). Retrieved February 16, 2017, from https://manuelmiroglio.files.wordpress.com/2011/05/el-turismo-de-naturaleza-en-mexico.pdf

Dirección de Desarrollo del Turismo Alternativo. (2016). Retrieved February 16, 2017, from http://dof.gob.mx/reglas_2016/SECTUR_30122015_01.pdf

Fullana, P.A. (2002). Sustainable Tourism. Barcelona, Ed. Rubes.

Graciet Paredes, P., \& Otros. (1994). Rural tourism. Ministry of Agriculture, Fisheries and Livestock.

Lillo, A., Ramón, A., \& Sevilla, M. (2006). A Framework for Analyzing Human Capital in Tourism.

Dialnet, 9, 45-59. Retrieved April 22, 2017, from

https://dialnet.unirioja.es/servlet/articulo?codigo $=2200649$

National Institute of Statistic and Geography. (2016). Mexico Tourism Satellite Account. INEGI.

Retrieved April 19, 2017, from

http://www.inegi.org.mx/est/contenidos/proyectos/cn/tur/default.aspx

National Institute of Statistics and Geography, 2015. (2016). System of National Accounts of Mexico:

Satellite account of tourism in Mexico 2015: Preliminary: Base year 2008 / National Institute of

Statistics and Geograph.-- Mexico: INEGI. (Mexico).

RITA. (2017). Indigenous Tourism Network of Mexico. Retrieved from

http://www.rita.com.mx/nosotros.html

Royal Spanish Academy. (2017). Real academy of the Spanish language. Madrid.

SECTUR, Ministry of Tourism. (2012). Performance evaluation of tourist destinations within the framework of the Coordination Agreements regarding the Reallocation of Resources (online).

Retrieved February 16, 2017, from http://cestur.sectur.gob.mx/index.php/publicaciones/estudiose-investigaciones/estudios-del-fondo-sectorial-conacyt-sectur

Tarlombani, M. (2005). Tourism and sustainability. Between speech and action. Stud. Perspect. Tur., 14(3). Autonomous City of Buenos Aires July / Sept.

UNESCO. (2006) Operational guidelines for the application of the convention for the safeguarding of the intangible cultural heritage. Documents. Retrieved February 2017, from http://www.unesco.org/culture/ich/ 2006 Proclamación de las obras maestras del patrimonio oral e inmaterial de la humanidad (2001-2005).

World Tourism Organization. (2016). UNWTO Technical Product Portfolio. UNWTO. Madrid. 